\title{
Designed to Fail: Media Representations of Racialized Classrooms and Schools
}

\author{
Cheryl Arntson
}

\begin{abstract}
Educational institutions are assumed to be racially neutral. However, media represents the achievement and ability of individual students and schools disparately and gives these attributes racial meaning. The scenes and sets in movies in the background seldom enter our consciousness and are assumed natural and normal in the context of movies and the stories they communicate. However, audiences, media institutions and set designers draw on shared cultural understandings to communicate and interpret the racial implications behind objects, placement of bodies, and scenery (Entman, 1993, pp. 52-53). Negative media portrayals of Black students and their school environments suggest that there is a problem with urban education. These representations and images suggest that the setting and the objects within it have purpose and meaning that is important in relaying the intended message. This study examines physical elements represented in classroom and school spaces in four movies: Akeelah and the Bee (2006), Finding Forrester (2000), Coach Carter (2005), High School Musical (2006). Utilizing a visual analysis of scenes depicting classrooms and school exteriors in these films, this study sought to examine how these representations of schools are presented as racialized spaces. Based on the data collected, the study concluded school spaces are represented disparately if they are assumed to contain Black racialized bodies than they are if they are assumed to be white spaces. Representations of urban schools with Black student populations contain multiple elements of surveillance, control and categorization.
\end{abstract}

Cheryl Arntson is a recent BA graduate of MacEwan University. In June of 2019, she convocated with distinction, majoring in the Sociology Family, Youth and Diversity stream, and minoring in History. Her academic interests revolve around a passion for understanding how an individual's or group's stories and histories come to affect their opportunities to fully participate in society. In her future endeavours, she hopes to combine her experience working as a dental hygienist with her knowledge of social inequalities to improve access to healthcare for marginalized groups. Her sincerest gratitude is extended to academic staff and students in the Sociology department at MacEwan. Specifically, she would like to acknowledge the academic mentorship of Dr. Kalyani Thurairajah, whose class in race and media studies inspired this paper, and Dr. Fiona Angus, who devoted time to teach an aspiring academic researcher to write an organized, focused paper. In addition, this paper is dedicated to her husband and three children who supported her unwaveringly while she pursued her full-time academic study and a dental hygiene career. 


\section{Introduction}

Educational institutions are assumed to be racially neutral. However, media represents the achievement and ability of individual students and schools disparately and gives these attributes racial meaning. The scenes and sets in movies in the background seldom enter our consciousness and are assumed natural and normal in the context of movies and the stories they communicate. However, Hollywood set designers are hired to create scenes in movies and television that communicate culturally and contextually appropriate messages. Audiences, media institutions and set designers draw on shared cultural understandings to communicate and interpret the racial implications behind objects, placement of bodies, and scenery (Entman, 1993, pp. 52-53). This suggests that the setting and the objects within it have purpose and meaning that is important in relaying the intended message. Entman (1993) asserts that media frames define problems, determine causational factors, make moral judgements and suggest solutions (p. 52).

Racialization is defined as a process in which the characteristics, practices and behaviors of populations and groups are assumed to be racially caused (Gans, 2017, p. 342). Therefore, visual signifiers of race, such as phenotypical skin colour, come to have social connotations and symbolic meanings. Racist stereotypes based on skin colour are essentialist and ignore the diversity of language, culture and ethnicity within the group. Black Americans can be defined as those individuals who reside in the United States of America who are racialized, or self identify, as Black. Although the term Black encompasses a diverse cultures and ethnicities, those individuals who are racialized as Black face similar racial discrimination and institutional barriers (pp. 346347).

Negative media portrayals of Black students and their school environments suggest that there is a problem with urban education. However, educational failure of Black students is not framed systemically or institutionally. Rather, Black students are constructed as ineducable and violent (Punyanunt-Carter, 2008, p. 243; Sealey-Ruiz \& Greene, 2015, p. 56; Toliver, 2017, p. 261, 621). Furthermore, they are often conflated with lower socioeconomic neighborhoods and judged to be drains on educational and social welfare systems (Reid-Brinkley, 2012, p. 78). These media frames legitimize and normalize the disproportionate administering of zero tolerance policies upon these students and urban schools. In addition, many see these negative stereotypes as being linked to what has come to be known as the school to prison pipeline.

This article examines how Hollywood movies visually represents the physical space of classrooms and schools in racialized ways that perpetuate negative stereotypes about Black students. Given that Black students are stereotyped as ineducable and dangerous, schools and classroom spaces for Black students in movies will be designed with multiple elements of social control. Conversely, school and classroom spaces for White students will lack explicit elements of social control because White students are assumed to be educable and compliant.

\section{Literature Review}

Stefanovici (2014) argues that Black Americans in two movies overcome negative stereotypes of popular media: Akeelah and the Bee (2006) and Finding Forrester (2000). The article acknowledges that stereotypes of Black individuals are historically constructed and are 
closely tied to class structures. Like other scholars, the author agrees that Black individuals are generally perceived as less intelligent than the dominant white class (p. 71). Furthermore, Stefanovici (2014) asserts that academic Black students face negative prejudices from their ethnic peers, often accused of "acting white" (p. 73). Stefanovici (2014) suggests that the characters' success despite these barriers is evidence that they overcome negative racial stereotypes.

However, in recognition of their exceptional ability, both movie protagonists are pressed to attend schools with predominantly White student populations outside of their districts. This implies that these institutions are white and inherently better (p. 74). The author argues that popular Black culture rejects education and that the characters in this movie take the "right path" by embracing education. Although the author acknowledges that children should not be characterized by "preconceived, racist ideas", the implication that assimilation to a "White" standard of education is the only route to meaningful success is racist (p. 75). The assumption conflates successful and appropriate educational institutions and students with "White" and concurrently correlates Black students and urban schools with educational failure. This racialization of educational achievement is problematic.

\section{Racialization}

Racialization is understood as a process giving racial meaning to a previously racially unclassified social relationship, practice or group (Gans, 2017, p. 342). The process of racialization marginalizes and subjugates individuals and groups. Thus, racialization is a form of "othering" where racialized groups are placed in comparison or opposition to the dominant or hegemonic group (p. 351). Social structures and institutions reflect, support and reinforce dominant ideologies that simultaneously racialize groups and benefit dominant groups economically and politically (p. 343). As an influential social institution, media is not neutral as it mediates these dominant ideologies to audiences. Black students and 'urban education' are constructed in media as problematic and in need of reform (Allweiss et al., 2015, p. 615).

Contemporary media representations of Black Americans are variations of common historical stereotypes (Gordon, 2016, p. 197). Black Americans are portrayed as intellectually inferior and uneducable (Toliver, 2017, p. 261). Furthermore, they are represented as having lower education levels (Punyanunt-Carter, 2008, p. 243), limited academic abilities, lack of motivation and a disinterest in education (Sealey-Ruiz \& Greene, 2015, p. 56; Toliver, 2017, p. 621). Black male students are overrepresented in special education and underrepresented in gifted education (Toliver, 2017, p.621). Typically, athleticism of Black American students is prioritized over their academic characteristics (Dancy, 2009, p. 21). In addition, representations of Black American youth, especially Black males, are deviantized and criminalized when represented as lazy, morally inept, fear inducing, and prone to mayhem (Toliver, 2017, p. 621). Although the quantity of representations of Black Americans on television has increased, the quality of these images has not (Punyanunt-Carter, 2008, p. 241).

Representations of Black American students are constructed in opposition to the hegemony of White, male, affluent academics. Dancy (2009) found that White men come to represent the "everyman" and "common-man" (p. 21). Consequently, White men can simultaneously inhabit the identities of "White", "collegiate" and "men" simultaneously (p. 21). Intellect is not associated 
with black masculinity and characters displaying intellectual capacity are often portrayed as being excluded by their ethnic group. This study provides a basis for understanding how "white" spaces can be invisibilized and privileged as the standard or norm. When examining spaces, "white" spaces may only be implicit. Care will need to be taken to deconstruct media frames around these spaces.

Persistent negative characterizations of Black Americans in media condition audiences to perceive the educational failures of Black students as normal (Toliver, 2017, p. 621). High levels of exposure to negative media stereotypes is associated with negative attitudes towards Black individuals, especially when audiences lack firsthand knowledge and experience to contradict these stereotypes (Punyanunt-Carter, 2008, p. 241). These stereotypes are also implicated in identity formation among Black American students who may perceive pressure to fulfill social expectations among their peers (Dancy II, 2009, p. 21). Furthermore, negative stereotypes influence and limit the social locations and identity possibilities for racialized groups and individuals and denies the power to position themselves (Gordon, 2015, p. 213; Toliver, 2017, p. 621).

Representations of success and achievement among Black American students are predicated on the construction of the "ghetto" at-risk youth narrative and gifted students are framed through a discourse of exceptionalism and tokenism rather than merit (Reid-Brinkley, 2012, p. 78). These narratives are bound to the ontological standard of whiteness (p. 79). Reid-Brinkley (2012) suggests that successful racialized individuals exist as an "outsider within" no longer belongs to any one group; occupy a borderland space between various communities (p. 79). This finding implies that racialized bodies experience space contextually. The author suggests that their experiences are framed in such a way that the audience is invited to understand their achievements as redemptive, saving them from their communities and their perceived negative outcomes (p. 79). Although this appears to transcend negative stereotypes, the author contends that the narrative is still grounded in racialized constructions of urban youth (p. 79).

Longstanding racial stereotypes become deeply embedded in institutions, policies and procedures that appear to operate as race neutral (Mitchell et al., 2010, p. 296). Media stereotypes influence teacher's perceptions of black students' capacities and abilities (Sealey-Ruiz \& Greene, 2015, p. 56), and legitimate school policies of educational intervention and punitive administrative control (Sealey-Ruiz \& Greene, 2015, p. 67; Toliver, 2017, p. 261). Decision makers rely on existing social myths and symbols about race and gender when forming policy and these policies and institutions play a role in producing, maintaining and reproducing racialized images and symbols (Allweiss et al., 2015, p. 626). Zero tolerance policies were born out of the belief that racialized and criminalized African-American student bodies and their behaviours need to be controlled (Sealey-Ruiz \& Greene, 2015, p. 67). The punitive consequences of zero tolerance policies are overrepresented in underfunded, urban schools and disproportionately enforced upon Black American students (Dancy II, 2014, p. 476; Toliver, 2017, p. 621). As a result, these children are less likely to graduate and are frequently funnelled into juvenile and criminal justice systems in a process that has come to be called the school-to-prison pipeline (Dancy II, 2014, p. 476). Consequently, scholars have become critical of the concept of schools being a race-neutral space (Sealey-Ruiz \& Greene, 2015, p. 70). 


\section{Racialization of Space}

Racialization of space is the process by which residential location and community carry racial meaning and come to symbolize the attitudes, values, behavioural inclinations and social norms of the kinds of people who are assumed to live there (Calmore, 1995, p. 1233). Inner-city youths of colour have become the symbols of poverty, crime and the failure of the public education system in U.S. media. Urban public spaces are portrayed as "overpopulated by dangerous Black male criminals who have made the public streets unsafe, [and] by 'public children' from the socalled Black underclass who consume educational and social welfare services far exceeding their value to society" (Patricia Hill Collins quoted in Reid-Brinkley, 2012, p. 81).

Schools are racialized spaces. Waymer (2016) found that historically black colleges and universities are perceived as poorly managed, outdated and a drain on the economy. This racialization diminishes the fact that these educational institutions produce research, educate students and benefit the communities in which they are located. Furthermore, the framing implies that the students in these institutions are unable to meet the standards of white institutions and consequently face lack of funding and closure (p. 502). Hollywood films depicting urban schools tend to be follow a predictable formula. They establish a bleak urban landscape full of graffiti, refuse and decay. In addition, Black American youth are frequently associated with crime, violence, teen pregnancy and poverty (Sealey-Ruiz \& Greene, 2015, p. 64). Conversely, suburban landscape is often constructed as safe, manicured, clean, open and green space. Typically, schools in the suburban neighborhoods are portrayed as private or elite academies with a predominantly White student population. Assumptions about the schools and the student populations within them influence how the space is conceived and affects how individuals interact within and with the

Spatial theorists, notably Lefebvre, suggest that space is socially constructed and serves the needs of the hegemonic group (Monreal, 2016, p. 30; Mitchell et al., 2010, p. 296). Furthermore, space contains meaning. Spaces are designed or produced in predictable ways that conform with hegemonic standards and expectations about what a space is intended for, how it will be used and who the space is meant for (Kellock and Sexton, 2018, p. 117). This implies that space is based on power relations privileging the dominant group. In addition, space is mutually inclusive and exclusive when it determines who is permitted entrance. Henri Lefebvre's theory of a spatial triad provides a framework for understanding how space is socially constructed. He theorized that space exists as perceived space, conceived space and lived in space.

Perceived space consists of the tangible, physical or material environment (Monreal, 2016, p. 30). Space is marked by certain physical features that reflect the expectations of the school and the community (Monreal, 2016, p. 33). In a school, this can include the décor and physical layout of the building or classroom. Conceived space encompasses how designers, decision makers and architects create abstract, mental enclosures, and codified visualizations based on assumptions about what the space should be used for (Kellock and Sexton, 2018, p. 117). Maps, blueprints, furniture placement and choice of objects to be placed in a space define boundaries and how a space is to be used as a place (Monreal, 2016, p. 30). Consciously or unconsciously, these decisions affect the experiences of the intended users. Lived in space is the representational space. Individuals attribute meaning to the spaces they inhabit based on subjective experiences (Kellock and Sexton, 2018, p. 118; Mitchell et al., 2010, p. 297; Monreal, 2016, p. 30). 
Understandings of racial identity are dependent on the contexts and spaces in which they are being interpreted. Institutionalized racial understandings are socially constructed and historically situated (Mitchell et al., 2010, p. 297). Furthermore, space constitutes a field of power that encodes the interests of various constituencies and is the site of ongoing contestation. Decision-making structures in education are influenced and controlled by hegemonic groups and their ideologies (p. 298). Institutional interpretations of race have significant material and psychic consequences for the ways that students of color experience schooling (p. 294). This study draws on the understanding that the "raced" nature of space serves to limit individuals of color in certain racialized representations, roles, contracts, hierarchies and other hegemonic processes (p. 296).

Foucault understood discourse to be the contextual, symbolic understanding of an issue by society (Mitchell et al., 2010, p. 297). According to his social control theory, the function of educational institutions is to assimilate students' behaviours and actions to a standard of white citizenship. Like mental institutions and penitentiaries, they are deliberately planned spaces that are intended to 'normalize' and enforce conformity (Kellock and Sexton, 2018, p. 116). Education is a form of disciplinary power used to maintain social order (Dancy, 2014, p. 478). Hegemonic groups and ideologies hold the power to define these standards of behavior and determine whether an individual conforms with or deviates from the norm or mainstream and documenting the judgement. Deviation from norm leads to punishment, rewards given to ability to stay within normal limits. These are White, male, elite standards historically based in colonialism. Dancy (2014) asserts that schools historically functioned to educate developing white males how to maintain the ruling class standards and hierarchies. Over time this led to the creation of different schooling systems to maintain the class divide (Dancy, 2014, p. 478).

According to Foucault's social control thesis, institutions confine selected groups as a method of controlling or isolating the socially undesirable (Dancy, 2014, p. 478).

Space tends to be divided into as many sections as there are bodies or elements distributed. One must eliminate the effects of imprecise distributions, the uncontrolled disappearance of individuals... Its aim was to establish presences and absences, to know where and how to locate individuals... to be able at each moment to supervise the conduct of each individual, to assess it, to judge it, to calculate its qualities or merits. (Foucault quoted in Mitchell et al., 2010, p. 301).

Drawing on Bentham's panopticon, Foucault suggests that social control is established by formal and informal means. Space is designed to facilitate the three major functions of social control: to monitor, to control and to categorize individuals and their behavior. For the purposes of this study, these functions of social control provide a basis for the coding of visual data from classroom and school scenes in the sample movies.

\section{Media Framing}

Entman's (1993) framing theory will provide an additional framework for the critical analysis of media representations of schools. Media framing theory provides a qualitative technique that seeks to identify the context in which media place facts (Waymer \& Street, 2016, 
p. 494). Images are not neutral. Rather, dominant discourses are communicated through stereotyped images, commonly understood phrases and key words which signify meaning (Allweiss et al., 2015, p. 627). Media frames influence how audiences interpret, remember and evaluate a problem through the employment of particular words, phrases, images, visuals, and/or common narratives (p. 613). Repetition of certain scripts reproduces and reinforces scripts that are intelligible for the intended audience (Reid-Brinkley, 2012, p. 84).

Media producers and communicators make conscious and unconscious choices about what to include and exclude, guided by frames or schemata that organize their belief system; text contains frames which are manifested by the presence or absence of certain keywords, stock phrases, stereotyped images, sources of information and sentences that provide thematically reinforcing clusters of facts or judgements (Entman quoted in Waymer \& Street, 2016, p. 493).

These media frames define and provide solutions to problems, suggest causal agents, and assign moral judgement (Entman, 1993, p. 52). Communicators and audiences draw on a store of culturally accepted frames to understand and interpret the media message (p. 52). Furthermore, framing can be used to promote or silence viewpoints (Waymer \& Street, 2016, p. 494). Allweiss et al. (2015) contend that neoliberal frameworks focussing on individualism and open markets assume that placing schools in competition with one another will improve the educational system for all. The researchers contend that this assumption is raced, classed and gendered. According to the article, "city/urban educational spaces become a battleground over access to opportunity, equity, and power. 'Urban' communities are pathologized and 'urban' education is framed as a problem. With the focus on individuals and communities, rather than the structure, the white-black achievement gap, poorly funded schools, poor teacher quality and unsupportive family structures are framed as student and community failures and problems to be solved" (Allweiss et al., 2015, p. 614).

Expanding on Allweiss et al. (2015) and Entman's (1993) media framing theory, this study attempted to examine the presence of symbolic images and visual elements of social control in movie scenes featuring classroom and school exterior settings. From the literature review, three research questions and a hypothesis emerged.

Research Question 1: Given that physical spaces hold meaning, is there evidence of racialized space in movie representations of classrooms and schools?

Research Question 2: Given that conceived space is based on assumptions about the intended use and users of the space, are educational spaces that are racialized "Black" designed differently from those educational spaces that are racialized "White"?

Research Question 3: If educational spaces are visually represented differently, are racialized "Black" educational spaces evidenced symbolically by images and objects of social control more frequently than "White" educational spaces? 
Hypothesis: Given that Black American students are stereotyped as ineducable and dangerous, schools and classroom spaces for Black students in movies will be designed with multiple elements of social control. Conversely, school and classroom spaces for White students will lack explicit elements of social control because White students are assumed to be educable and compliant.

\section{Methods}

Data sources for this study relied on purposive sampling. Samples were drawn from a population of North American movies, produced between the years 2000 and 2010, that featured middle school or high school storylines and characters. The production date of the films was deemed significant as the intent was to capture movies with contemporary narratives set within the timeframe of the implementation of zero tolerance policies developed in the United States during the 1980s and 1990s. The focus of the study was to examine the racialization of education in the media. Therefore, efforts were made to ensure that data included urban schools and classrooms, suburban schools and classrooms or visual images of both. Additionally, as the racialized group under study was Black American students, films were chosen that included characters in this racialized group either as the protagonist or supporting characters. Four data sources were selected for study: Akeelah and the Bee (2006), Finding Forrester (2000), Coach Carter (2005), High School Musical (2006).

Each of the movies selected featured students in middle school or high school. Two of the movies, Akeelah and the Bee (2006) and Finding Forrester (2000), contained representations of urban schools with predominantly Black American students as well as suburban schools with predominantly White student populations. Coach Carter (2005) was set in an urban, predominately Black American school, and High School Musical (2006) was set in a suburban, predominately White school. To ensure that the focus was on the visual elements of the scene and not language or the interrelationships of characters the films were viewed without sound.

Visual analysis of the movies focussed exclusively on scenes depicting the exterior of the schools and the classroom. These scenes were coded based on Foucault's theory of social control for visual elements of monitoring, control, and categorization. Monitoring was defined as the inclusion of elements such as police presence, cameras, metal detectors and desk arrangements that facilitated individual monitoring. Control was defined as the inclusion of physical elements that limited the freedom of movement or designated inclusion or exclusion to a space. Elements such as barriers, bars on windows, fences, locks and designated spaces were coded as control. Categorization was defined as physical evidence of testing or of individuals being set apart or singled out. This could include visual elements such as tests or characters being separated from the group punitively or beneficially.

\section{Findings}

General Findings

In all four movies urban or inner-city schools were portrayed as having predominantly Black American school populations. Furthermore, suburban and elite schools were portrayed with 
a predominantly White student population. This finding is consistent with research that suggests that images of urban schools and urban students are racialized as "Black" (Allweiss et al., 2015, p. 615). The results of the visual analysis of all four movies were consistent with the research hypothesis. The physical space of the classroom and the school exteriors of urban schools with predominantly Black American student populations consistently contained multiple elements of social control. Elements of surveillance, control and categorization were not salient in the visual representations of the school exteriors and classrooms of the suburban and elite schools. However, when Black American students, as racialized bodies were placed in these "White" spaces, there appeared to be evidence that these students were being individually targeted for punishment. This was most evident in the interpersonal relationships of teachers and African American students. As interactions between characters was beyond the scope of this study, they were not considered in the conclusions.

\section{Monitoring}

All portrayals of urban and inner-city schools contained multiple elements of surveillance or monitoring. Explicit and coercive elements of monitoring were consistently depicted in the movies which included scenes of urban high schools. For example, the high school entrance in Coach Carter (2005) was monitored with a metal detector and security guards. Police presence was also noted in exterior scenes in Finding Forrester (2000). Furthermore, classrooms in urban schools were consistently placed in single rows. This placement of desks is indicative of a form of surveillance as individuals can readily be singled out for deviant behaviour and punishment. For example, in Akeelah and the Bee (2006), Akeelah starts the movie in an urban school. Scenes depicting Akeelah's urban classroom featured individual desks in single rows. These findings are consistent with Foucault's understanding of institutional structures that are set up to segregate and separate individuals for the purposes of monitoring and categorizing individuals and their behaviours (Mitchell et al, 2010, p. 301).

This was not the case in elite and suburban schools where students were often placed in groups. When Akeelah is invited by a fellow competitor to join his friends in preparing for the spelling bee, she finds herself in a middle-class suburban school. The classrooms contrast with her urban school environment. A glimpse in the science classroom demonstrates that children are actively engaged in learning without the supervision of teachers. The classroom features tables and chairs rather than desks in single rows. This arrangement implies that students at this school do not require monitoring because their behaviour conforms to the rules and standards of the institution.

In Finding Forrester (2000), students at the elite Maillor academy are seated like an audience at a theatre or students in a university lecture hall. This implies that the space is academic. Although the teacher is situated in a traditional authoritarian position at the front of the classroom, the grouping of students makes the monitoring of individuals for culpability and punitive measures more complex than if the students were separated in individual desks. Despite this grouping, scenes from the classroom often depicted Jamal being singled out by the teacher. This finding demonstrates that when racialized individuals enter a white space, such as an elite, predominantly White school, they can become the individualized target of social control. 
One exception occurred in High School Musical (2006). Students were observed seated at individual desks in a drama class. The scene appeared to involve a punishment for use of cell phones during the class. The perpetrators, who were all White students, were identified, their cell phones were taken away and they were given detentions. Interestingly, further punishments were administered to the only two Black students in the classroom were also targeted in the punitive action even though they did not directly participate in the cell phone use. Their infraction appeared to be protesting the detentions given to their White classmates. This data supports the argument that racialized bodies in a white space become the individualized targets of social control.

Depictions of both urban and suburban schools placed the teacher or authority in the front of the classroom. However, depictions of urban classrooms were more likely to have the teacher facing the classroom and monitoring student activity. The classroom scene in Highschool Musical (2006) described previously locates the drama teacher in the front of the classroom. It is the drama room and the front of the classroom is the stage. It is presumed that students are occasionally permitted to enter the space at the front of the classroom when acting out plays. This diminishes the monitoring role of the authority or teacher in the classroom as this space appears to be fluid. Although the students' desks are placed in single rows in this classroom, scenes in the science lab and other classrooms show students grouped at tables or lab counters. The teacher is not always present to monitor student activities and in the science lab a high shelf in the center of the lab counter restricts direct monitoring of all students.

\section{Control}

Evidence of control was prevalent in urban school representations. Urban school depictions often relied heavily on the traditional scripts of urban spaces and poverty. The school building is imagined as an industrial, non-descript and colorless structure. Graffiti on the walls and litter in the courtyard suggest urban decay and an element of danger that needs to be controlled. The school space often featured high fences that separated the school from the rest of the community. Of interest, in Finding Forrester (2000) the high fence surrounding the school yard entrance is curved inward toward the school which suggests not only control and definition of the school space but also indicates that the purpose of the fence is to contain the inhabitants of the space and prevent individuals from escaping rather than keeping students safe from an outside threat. Furthermore, exterior windows of the schools were barred.

Urban classrooms all contained locked filing cabinets indicating that access to certain educational materials and spaces was not permitted. The limited textbooks or learning materials were consistently located at the front of the classroom near the teacher. This indicates that use of these materials is controlled, perhaps due to their limited supply, by the teacher. In Finding Forrester (2000), the classroom featured posters on drug use and the portrait of Edgar Allan Poe, a drug addicted poet whose inclusion in and urban classroom implies that there is some assumed commonality between Poe and the Black American students.

Conversely, suburban schools were portrayed as freer spaces for students. In Akeelah and the Bee (2006), the suburban school she visits features broad, open green spaces designed for multiple uses, open play and socializing. This area is vast and devoid of fences or definitive indications of boundaries. Barriers to the entrances of suburban schools were absent in most cases. 
When they were present, they were depicted as low-level barriers that loosely define the school yard. Typically, elite White racialized schools were depicted with large green spaces. Interestingly, in Finding Forrester (2000), Maillor academy is depicted in an urban environment. However, the exterior of the building is clean, manicured and lacking separation from the entrance and the sidewalk or city. The doors of the entrance are glass and devoid of locks. These images imply that the school space is a public space and available for free access to the local community. The fluidity of the space implies that the presumed students and the community surrounding the school need not live in fear of each other.

Books in suburban class rooms were often placed on open shelves throughout the room offering free access to educational resources. In Finding Forrester (2000), classic literature lines the walls of the classroom at Maillor academy and books are shown being passed out to the students. This design element is significant as it communicates the message that students in the school have free access to educational materials. High School Musical (2006) also depicted students having free access to spaces in the school. For example, in one scene, students are shown revealing a supportive message to athletes on a whiteboard in the classroom.

\section{Categorization}

Akeelah and the Bee (2006) and Finding Forrester (2000) shared themes of gifted students being rescued from their urban school environment. Although Akeelah remains an urban student throughout the film, a scene early in the movie shows her receiving an A+ on a spelling exam. The rest of the students in the class receive no more than a $\mathrm{C}$-. The results set her apart and suggest that she is the different. She becomes the exception through her achievement. In Finding Forrester (2000), Jamal finds himself taken from his urban school to an elite academy. Like Akeelah, it appears that his academic, and athletic, ability have differentiated him from other African American students in his school. This is consistent with research that has found the framing of options for gifted African American students is often limited to either staying in a failing school or taking advantage of the opportunities offered by an educational institution that is defined as superior and is often racialized White (Allweiss et al., 2015, p. 626).

Coach Carter (2000), contained very few classroom scenes. This may be due to the movies' narrative focussing on athletics rather than academics. Studies have found that representations of Black American students tend to prioritize athleticism over academic achievement (Dancy, 2009, p. 21). However, in one classroom scene, one of the athletes is returned an exam. This achievement is rewarded by the athlete's return to sports. High School Musical (2005) contained no scenes, exterior or interior, which demonstrated a categorization of individuals based on academic ability.

\section{Conclusions}

Black American students are stereotyped as being ineducable and dangerous. Zero tolerance policies unfairly and disproportionately target these youth. Media reproduces and perpetuates these stereotypes by framing these students and their schools in narrowly defined ways. This study sought to examine the representations of school exteriors and the classrooms in 
movies in order to discover how schools are presented as racialized spaces. From the findings we can conclude that school spaces are represented disparately if they are assumed to contain Black racialized bodies than they are if they are assumed to be white spaces. Representations of American urban schools with Black student populations contain multiple elements of surveillance, control and categorization.

This would imply that the individuals who this building was designed for are deviant and require stringent social control. Entman's (1993) framing theory suggests that media frames define a problem, suggest a causal factor, make moral judgements and offer solutions (p. 52). Using this theory as a framework, the sets in these movies suggest that inner-city schools are dangerous places because they have high populations of Black American students who are inherently violent and incapable of learning. Individual exceptions exist and need to be rescued from these systems. For those students that remain behind, the solution offered is to contain them until they grow up and are incarcerated.

This study was limited to the perceived and conceived spaces in these films. A deeper understanding of how schools are racialized should include the lived spaces of these schools. Including how people related to one another within a space would broaden the scope of our understanding of how students and teachers perceive and utilize school space. Society needs to consider carefully how school spaces influence our identity formation and create barriers to equitable access to education. Zero tolerance policies are implicitly and explicitly racially biased and impede the ability of Black American students to achieve academic success. Further limitations of the study related to the method of sample selection. Due to lack of time and resources, purposive sampling was used to select films that would provide representations of students who were Black American and schools that were urban or inner-city. However, these films only represent American films produced between the years of 2000 and 2010. Future research may wish to examine movie productions from years prior or more contemporary films for similar evidence of social control. In addition, acknowledgement must be made that alternative or oppositional readings of media images exist (Reid-Brinkley, 2012, p. 95).

Dancy (2014) equates the spatial division of races, physically and symbolically, to "de facto racial segregation" (p. 481). This segregation exists despite the achievements of the civil rights movement and formal legislation guaranteeing educational rights for African Americans and desegregation laws (p. 481). The author contends that post racial discourses obscure institutional power and ignore the racial barriers that create disadvantages for Black American youth (p. 479). Scholars have found that media representations can challenge harmful ideological constructions of Black individuals and "disrupts the power structure of knowledge production and construction. (Toliver, 2017, p. 626). Other scholars have suggested the need to recognize and subsequently contest institutional norms that lead to the continued perception of schools as white-only spaces (Mitchell et al, 2010, p. 304). Remaining conscious of and critical of the seemingly "natural" depictions of urban schools and Black American students reveals that space is meaningful and consequential to those that inhabit it. 


\section{References}

Allweiss, A. \& Grant, C.\& Manning, K. (2015). Behind the photos and the tears: media images, neoliberal discourses, racialized constructions of space and school closings in Chicago. Race, Ethnicity and Education, 18 (5), 611-631. http://dx.doi.org/10.1080/13613324.2014.969223

Atchison, D. (Director). (2006). Akeelah and the Bee [DVD]. Los Angeles, CA: Lionsgate Films.

Calmore, John O. (1995). Racialized space and the culture of segregation: 'hewing a stone of hope from a mountain of despair.' (Symposium-Shaping American Communities: Segregation, Housing \& the Urban Poor). University of Pennsylvania Law Review, Business Insights: Essentials.

1233-1273. http://bi.galegroup.com.ezproxy.macewan.ca/essentials/article/GALE\%7CA17237438/b0 5ebcf13508215bd28826a315d713cf?u=edmo87290

Carter, T. (Director). (2005). Coach Carter [DVD]. Hollywood, CA: Paramount Pictures

Dancy, T. (2009). Black Men on Campus: What the Media Do Not Show Us. Diverse: Issues in Higher Education. 25 (26), 21. ISSN:1557-5411 Accession number: 36489366

Dancy, T. (2014). (Un)Doing Hegemony in Education: Disrupting School-to-Prison Pipelines for Black Males. Equity \& Excellence in Education, 47 (4), 476-493. DOI: $10.1080 / 10665684.2014 .959271$

Entman, R. (1993). Framing: Towards Clarification of a Fractured Paradigm. Journal of Communication, 43 (4), 51-58. Retrieved from https://doi.org/10.111/j.14602466.1993.tb01304.x

Gans, H. (2017). Racialization and racialization research. Ethnic and Racial Studies, 40 (3), 341352. https://doi.org/10.1080/01419870.2017.1238497

Gordon, M. (2015). Achievement Scripts: Media Influences on Black Students' Academic Performance, Self-Perceptions, and Career Interests. Journal of Black Psychology, 42 (3), 195-220. Doi: 10.1177/0095798414566510

Kellock, A. \& J. Sexton (2018). Whose space is it anyway? Learning about space to make space $\begin{array}{lllll}\text { to learn. } \quad \text { Children's } & \text { Geographies, } & 16 & \text { (2), }\end{array}$ https://doi.org/10.1080/14733285.2017.1334112

Mitchell, R. \& G. Wood, N. Witherspoon (2010). Considering Race and Space: Mapping Developmental Approaches for Providing Culturally Responsive Advising. Equity \& Excellence in Education, 43 (3), 294-309. https://doi.org/ 10.1080/10665684.2010496691

Monreal, T. (2016). Is the 'Space' for International Baccalaureate? A case study exploring space and the adoption of the IB Middle Year Programme. Current Issues in Comparative Education, 19 (1), 26-42. ISSN: 15231615, Accession Number: EJ1128148 
Ortega, K. (Director). (2006). High School Musical [DVD]. Burbank, CA: Walt Disney Films.

Punyanunt-Carter, N. M. (2008). The Perceived Realism of African American Portrayals on Television. The Howard Journal of Communications, 19, 241-257. https://doi.org/10.1080/10646170802218263

Reid-Brinkley, S. R. (2012). Ghetto Kids Gone Good: Race, Representation, and Authority in the Scripting of Inner-City Youths in the Urban Debate League. Argumentation and Advocacy, 49 (2), 77-99, https://doi.org/10.1080/00028533.2012.11821781

Sealey-Ruiz,Y. \& P. Greene (2015). Popular Visual Images and the (Mis)Reading of Black Male Youth: a case for racial literacy in urban preservice teacher education. Teaching Education, 26 (1), 55-76. https://doi.org/10.1080/10476210.2014.997702

Stefanovici, S. (2014). Black Stereotypes in American Movies. Studia Universitatis Petru Maior - Philologia, 17, 70-75. http://content.ebscohost.com/ContentServer.asp?EbscoContent=dGJyMMvl7ESep7Y4y9 fwOLCmr1Gep7BSsKa4S7WWxWXS\&ContentCustomer=dGJyMPGqt0uyrLVRuePfge yx43zx 1\%2B6B \&T=P\&P=AN\&S=R\&D=ufh\&K=100634887

Toliver, S.R. (2017). Unlocking the Cage: Empowering Literacy Representations in Netflix's Luke Cage Series. Journal of Adolescent \& Adult Literacy, 61 (6), 621-630. https://doi.org/10.1002/jaal.721

Van Sant, G. (Director). (2000). Finding Forrester [DVD]. USA: Columbia Pictures.

Waymer, D. \& J. Street (2016). Second-class, cash strapped, antiquated institutions: Unbalanced media depictions of historically black colleges and universities in the chronicle of higher education. Journal for Multicultural Education, 10 (4), 489-506. https://doi.org/ 10.1108/JME-02-2015-0004 